\title{
BIOCHEMISTRY OF MENINGIOMAS
}

\author{
COPPER, CERULOPLASMIN, MAGNESIUM AND SULFUR CONTENTS IN THE \\ BLOOD SERUM, AND CALCIUM, PHOSPHORUS, COPPER, MAGNESIUM, SODIUM \\ AND POTASSIUM CONTENTS IN THE TUMORAL TISSUE
}

\author{
Horacio M. Canelas * \\ Francisco B. De Jorge ** \\ Rolando A. Tenuto ***** \\ WALTER C. Pereira *** \\ JAMIL SALLUM $* * * * *$
}

A series of investigations has evidenced, in the blood serum of patients with several types of neoplasms, an increase of the concentrations of sulfur 15, 16, 17 and copper $22,25,28,29,30$, this latter being most likely related to the non-ceruloplasmin fraction 15, 16,17. Data on the magnesemia in such cases are variable $15,16,19,31$.

In tumors grown in non-nervous tissues an increase of $\mathrm{Cu}$ has also been found $15,16,17,21,26,33$. In the rat hepatoma a rise of $\mathrm{Mg}, \mathrm{K}$ and $\mathrm{Na}$ was observed ${ }^{27}$. Regarding the neoplasms of the central nervous system, Grashchenkov and Hekht ${ }^{20}$ found an increase of $\mathrm{Cu}$ contents. Alexander and Myerson 1, comparing the composition of a spongioblastoma with the normal grey matter, found higher values of $\mathrm{K}$, lower values of $\mathrm{Mg}$ and $\mathrm{P}$, and similar levels of $\mathrm{Na}$. Higher concentrations of $\mathrm{Ca}$ were found in two-thirds of 25 gliomas studied by Wender and Hierowski ${ }^{32}$; in 60 per cent of the cases $\mathrm{Na}$ was increased, while $\mathrm{K}$ was lowered; in a third of cases, however, $K$ levels were higher than in normal brain tissue. Studying the biochemistry of 9 astrocytomas, 10 glioblastomas and 10 medulloblastomas as compared to the normal brain tissue, Canelas et al. ${ }^{6}$ found higher contents of $\mathrm{Ca}, \mathrm{Cu}$ and $\mathrm{Mg}$, irrespective of the histological pattern; the levels of $\mathrm{Na}$ were higher in astrocytomas and glioblastomas, $\mathrm{K}$ showed a trend to higher levels in astrocytomas, and the values of $P$ were higher in glioblastomas and medulloblastomas.

In a survey of the literature on meningiomas we have only found studies on some organic components of the tumors, such as fatty acids, phospholipides, lipides in general, and mucopolysaccharides.

A study has been made of $\mathrm{Cu}$, ceruloplasmin, $\mathrm{Mg}$ and $\mathrm{S}$ contents in the blood serum of patients with meningiomas, as well as of $\mathrm{Cu}, \mathrm{Mg}, \mathrm{Ca}, \mathrm{P}$, $\mathrm{K}$ and $\mathrm{Na}$ concentrations in the tumor itself. The results were compared with the normal values in the serum and in the dura mater (it is well

From the Departments of Neurology (* Associate Professor, *t Assistant Neurosurgeon, *** Chief Neurosurgeon), Medicine $(* *$ Chief of Laboratory), and Pathology $(* * * *$ Neuropathologist), University of São Paulo Medical School. 
known that meningiomas arise in the arachnoid membrane; however, owing to the difficulties for the isolated removal of the arachnoid, the concentrations in the normal dura mater of human brain ${ }^{5}$ were used as control in the comparative studies, a method already adopted by Cain et al. 4 in a similar investigation).

\section{MATERIAL AND METHODS}

Specimens of 9 meningiomas were studied. Seven tumors were in the supratentorial region and two were intraspinal in location (Table 1). These latter and one intracranial neoplasm were of the psammomatous type; from the remaining 6 cases, 4 were of the meningotheliomatous type and 2 of the fibroblastic type, according to Bailey and Bucy ${ }^{2}$ classification.

Eight patients were female; 8 were white and 1 was negro. Ages varied from 23 to 60 years. Symptoms had lasted from 1 to 10 years. The largest diameter of the intracranial tumors varied between 5 and $8 \mathrm{~cm}$; in the intraspinal meningiomas it was of $2 \mathrm{~cm}$. Calcifications were seen at the X-ray examination in 4 cases of intracranial tumor (Table 1).

In the blood serum of 8 patients the concentraticns of $\mathrm{Cu}$, ceruloplasmin, $\mathrm{Mg}$ and $\mathrm{S}$ were determined. In the tumoral tissue of the same patients plus one $\mathrm{Cu}, \mathrm{Mg}, \mathrm{Ca}, \mathrm{P}, \mathrm{Na}$ and $\mathrm{K}$ contents were determined. The results were submitted to conventional statistical analysis ${ }^{3}$.

Immediately after remotion the tumoral samples were placed in a glass container with a plastic cover and put in a freezer. Afterwards each sample was collected in a porcelain crucible and heated at $100^{\circ} \mathrm{C}$ for approximately hr. until a constant weight was reached. The samples were ashed in a furnace overnight at $550^{\mathrm{a}} \mathrm{C}$. The ashes were dissolved in a known volume of $2 \mathrm{~N}-\mathrm{HCl}$. In this solution $\mathrm{Na}$ and $\mathrm{K}$ were determined by flame spectroscopy in a Coleman model 20; $\mathrm{Ca}$ by the Clark and Collip " method; $\mathrm{P}$ by that of Fiske and Subbarow ${ }^{18}$; $\mathrm{Mg}$ by the yellow titan method ${ }^{13} ; \mathrm{S}$ by the turbidimetric method described elsewhere ${ }^{14}$. Copper was determined by the diethyldithiocarbamate method ${ }^{8}$; all reagents were tested for copper contamination; the water used in all operations was redistilled

\begin{tabular}{cccccccc}
\hline $\begin{array}{c}\text { Case } \\
\text { No. }\end{array}$ & $\begin{array}{c}\text { File } \\
\text { No. }\end{array}$ & $\begin{array}{c}\text { Age-Sex- } \\
\text { Race }\end{array}$ & $\begin{array}{c}\text { Duration of } \\
\text { symptoms } \\
\text { (years) }\end{array}$ & Location & $\begin{array}{c}\text { Largest } \\
\text { diameter } \\
\text { (cm.) }\end{array}$ & $\begin{array}{c}\text { Calcif. } \\
\text { (X-rays) }\end{array}$ & $\begin{array}{c}\text { Histologic } \\
\text { type }\end{array}$ \\
\hline \hline 1 & 4675 & $60-\mathrm{F}-\mathrm{W}$ & 10 & Frontal & 08 & + & Meningoth. \\
2 & 6236 & $45-\mathrm{F}-\mathrm{W}$ & 15 & Temporal & 07 & 0 & Meningoth. \\
3 & 6264 & $45-\mathrm{F}-\mathrm{W}$ & 01 & Spinal & 02 & - & Psammomat. \\
4 & 6273 & $55-\mathrm{F}-\mathrm{W}$ & 02 & Temporal & 07 & + & Meningoth. \\
5 & 6287 & $59-\mathrm{F}-\mathrm{W}$ & Unknown & Parietal & 06 & 0 & Meningoth. \\
6 & 6366 & $27-\mathrm{F}-\mathrm{N}$ & 08 & Parietal & 06 & + & Psammomat. \\
7 & 6685 & $63-\mathrm{F}-\mathrm{W}$ & 01 & Spinal & 02 & - & Psammomat. \\
8 & 6773 & $41-\mathrm{F}-\mathrm{W}$ & 05 & Temporal & 05 & + & Fibroblast. \\
9 & 7247 & $23-\mathrm{M}-\mathrm{W}$ & 02 & Parieto- & 08 & 0 & Fibroblast.
\end{tabular}

Table 1 - Material: $F=$ female; $M=$ male; $W=$ white; $N=$ negro; $+=$ present; $0=$ absent; $-=$ not searched for. 
in an all-glass distiller; the glassware used for analytical determinations was soaked overnight in chromic acid and washed thoroughly with redistilled water; the material was boiled in a 20 per cent $\mathrm{HCl}$ solution for $2 \mathrm{hr}$., washed with redistilled water, and put in an oven to dry within a glass container.

The results are expressed in mequiv. $/ 100 \mathrm{ml}$. (blood serum) or mequiv. $/ 100 \mathrm{~g}$. dry weight (tumoral tissue) for $\mathrm{Mg}$, $\mathrm{Na}, \mathrm{K} ; \mathrm{mg} / 100 \mathrm{ml}$. or $\mathrm{mg} / 100 \mathrm{~g}$. for $\mathrm{Ca}$, $\mathrm{P}, \mathrm{S} ; \mu \mathrm{g} / 100 \mathrm{ml}$. or $\mu \mathrm{g} / 100 \mathrm{~g}$. for $\mathrm{Cu}$; and $\mathrm{mg} / 100 \mathrm{ml}$. for ceruloplasmin. The results 'were compared with the normal values in the blood serum $8,10,11,12$ and in the human dura mater ${ }^{5}$.

\section{R E S U L T S}

The blood serum values of $\mathrm{Cu}$, ceruloplasmin, $\mathrm{Mg}$ and $\mathrm{S}$ were significantly nigher than the normal levels (Table 2). Although the correlation between $\mathrm{Cu}$ and copper-oxidase was highly significant $(r=0.9)$ the difference of means of $\mathrm{Cu}$ is more significant than that of ceruloplasmin.

\begin{tabular}{|c|c|c|c|c|c|}
\hline & Case No. & $\begin{array}{c}\text { Copper } \\
(\mu \mathrm{g} / 100 \mathrm{ml})\end{array}$ & $\begin{array}{l}\text { Ceruloplasmin } \\
(\mathrm{mg} / 100 \mathrm{ml})\end{array}$ & $\begin{array}{c}\text { Magnesium } \\
\text { (mequiv } / 100 \mathrm{ml} \text { ) }\end{array}$ & $\begin{array}{l}\text { Sulphur } \\
(\mathrm{mg} / 100 \mathrm{ml})\end{array}$ \\
\hline \multirow{9}{*}{ 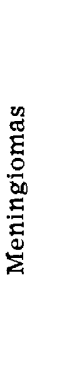 } & 01 & 164 & 38.4 & 2.659 & 一 \\
\hline & 02 & 315 & 36.5 & 2.272 & 2.528 \\
\hline & 03 & 310 & 35.0 & 2.500 & 2.349 \\
\hline & 04 & 266 & 40.0 & 2.950 & 1.953 \\
\hline & 05 & 226 & 58.0 & 2.272 & 1.569 \\
\hline & 06 & 171 & 30.2 & 2.500 & 1.957 \\
\hline & 07 & 229 & 35.8 & 1.986 & 2.454 \\
\hline & $\mathrm{Cg}$ & 180 & 32.6 & 3.267 & 2.066 \\
\hline & Mean & $233 \pm 60$ & $38.3 \pm 8.5$ & $2.551 \pm 0.408$ & $2.124 \pm 0.340$ \\
\hline \multirow{6}{*}{ 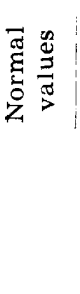 } & Mean & $108.1 \pm 9.7(11)$ & $33.4 \pm 3.1(9)$ & $2.087 \pm 0.067(12)$ & $1.222 \pm 0.193(13)$ \\
\hline & $\mathrm{n}$ & 80 & 65 & 130 & 40 \\
\hline & Method & $\begin{array}{l}\text { Diethyldithio- } \\
\text { carbamate (10) }\end{array}$ & Houchin (23) & Yellow titan(16) & $\begin{array}{l}\text { Turbidime- } \\
\text { tric(17) }\end{array}$ \\
\hline & Difference & 124.9 & 4.9 & 0.464 & 0.902 \\
\hline & $\mathrm{t}$ & 9.234 & 3.286 & 11.252 & 10.084 \\
\hline & $P$ & $<0.001$ & $<0.001$ & $<0.001$ & $<0.001$ \\
\hline
\end{tabular}

Table 2 - Concentrations of chemical constituents in the blood serum, and comparison with the normal values. Normal mean values: into parentheses, the reference numbers.

In the tumoral tissue, the average concentrations of all the elements studied were significantly higher than those of the normal dura mater of human brain (Table 3). If this comparison was made considering apart the 3 psammomatous and the 6 meningotheliomatous or fibroblastic meningiomas, the same result was found, except for $\mathrm{Ca}$ content in the latter group, which did not differ statistically from the levels of normal meninx. 


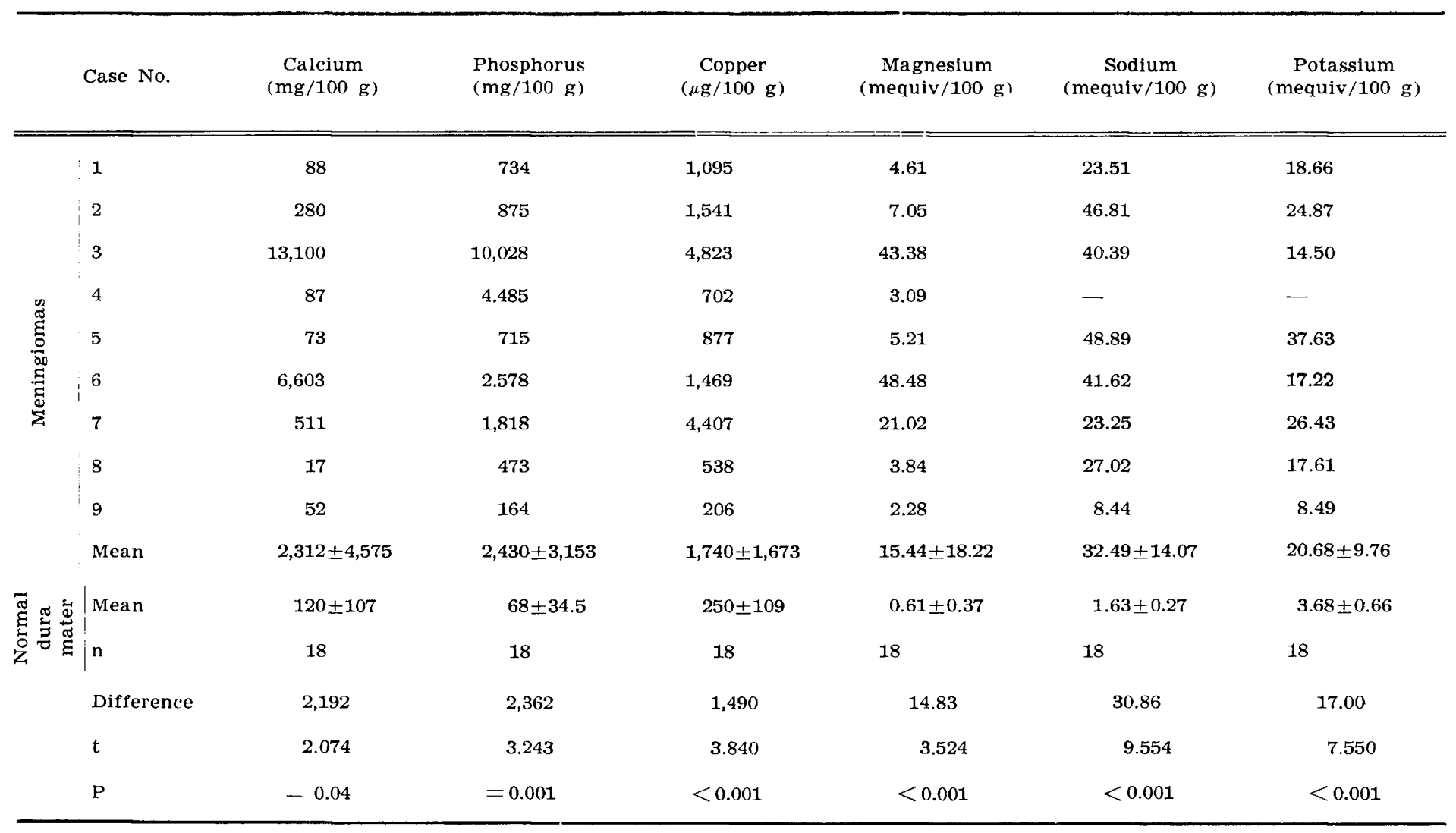

Table $s$ - Concentrations of, chemical constituents (dry weight) in tumoral tissue and comparison with the concentrations in normal human dura-mater. 
The average concentrations of the elements in the psammomatous meningiomas were compared to the averages in the other types as a whole (Table 4). The levels of $\mathrm{Ca}, \mathrm{Cu}$ and $\mathrm{Mg}$ were significantly higher in the psammomatous type than in the others.

\begin{tabular}{|c|c|c|c|c|c|}
\hline Elements & $\begin{array}{c}\text { Histol } \\
\text { Psammo- } \\
\text { matous } \\
\text { (3 samples) }\end{array}$ & $\begin{array}{l}\text { ogic type } \\
\text { Meningothe- } \\
\text { liomatous and } \\
\text { fibroblastic } \\
\text { ( } 6 \text { samples) }\end{array}$ & $\begin{array}{l}\text { Diffe- } \\
\text { rence } \\
\text { of } \\
\text { means }\end{array}$ & $\mathrm{t}$ & \\
\hline $\mathrm{Ca} \quad(\mathrm{mg} / 100 \mathrm{~g})$ & $6,738 \pm 6,296$ & $99 \pm 73$ & 6,639 & 2.790 & $0.05>P>0.02$ \\
\hline $\mathrm{P} \quad(\mathrm{mg} / 100 \mathrm{~g})$ & $4,808 \pm 4,537$ & $1,241 \pm 1,609$ & 3,567 & 1.815 & $0.2>\quad P>0.1$ \\
\hline $\mathrm{Cu} \quad(\mu \mathrm{g} / 100 \mathrm{mg})$ & $3,566 \pm 1,828$ & $826 \pm 443$ & 2,740 & 3.702 & $0.001>\mathrm{P}>0.01$ \\
\hline $\mathrm{Mg}$ (mequiv/100 g) & $37.63 \pm 14.61$ & $4.35 \pm 1.69$ & 32.28 & 5.930 & $<0.001$ \\
\hline $\mathrm{Na}$ (mequiv/100 g) & $35.09 \pm 10.27$ & $30.93 \pm 16.96 *$ & 4.16 & 0.378 & $0.8>P>0.7$ \\
\hline $\mathrm{K}$ (mequiv $/ 100 \mathrm{~g}$ ) & $19.38 \pm 6.25$ & $21.45 \pm 10.77^{*}$ & 2.07 & 0.298 & $0.8>\mathrm{P}>0.7$ \\
\hline
\end{tabular}

Table 4 - Mean concentrations of chemical constituents (dry weight) in the group of psammomatous menirgiomas and in the other types (meningotheliomatous and fibroblastic) as a whole: * Five samples.

Significant correlations were found between the contents of $\mathrm{Ca}$ and $\mathrm{P}, \mathrm{Ca}$ and $\mathrm{Mg}, \mathrm{P}$ and $\mathrm{Cu}$, and $\mathrm{Cu}$ and $\mathrm{Mg}$ in the tumoral tissue of the whole group, while the correlations of $\mathrm{Ca}$ and $\mathrm{Cu}$, and $\mathrm{P}$ and $\mathrm{Mg}$ showed a trend $(0.1>P>0.05)$ to significant levels.

No significant correlation was found between the concentration of the elements in the neoplastic tissue and the duration of symptoms or the tumor size, except a negative correlation $(r=-0.98)$ between $\mathrm{Cu}$ levels and tumor size, and a trend to a negative correlation between tumor size and $\mathrm{P}$ levels $(r=-0.5)$ and $\mathrm{Mg}(r=-0.6)$.

The concentrations of $\mathrm{Cu}$ and $\mathrm{Mg}$ in the blood serum did not evidence correIation with those in the tumoral tissue.

\section{O M M E T S}

Concerning the blood serum levels of $\mathrm{Cu}$ and $\mathrm{S}$ our results confirm the literature data pointing to an increase of them in patients with neoplastic diseases $15,16,17,22,25,28,29,30$. The increased magnesemia is in accordance with the findings in fibroleiomyomas and cancer of the breast and larynx 15, 16, 17.

In the tumoral tissue our results also agree with the findings of increased concentrations of $\mathrm{Ca} 6,32, \mathrm{Cu} 6,15,16,17,21,26,33, \mathrm{Na} 6,27,32$, $\mathrm{Mg}^{6,27}$ and $\mathrm{K}^{27}$ in various kinds of neoplams.

Ca levels in the tumoral tissue showed an extremely wide range of variation. Nevertheless, it must be emphasized that significantly higher 
values were found in the three cases of psammomatous tòpe than in the meningotheliomatous and fibroblastic types as a whole (table 5). This findings agrees with the results of $\mathrm{Huh}^{24}$ : calcification was histologically detected in 100 per cent of 52 psammomatous meningiomas, while in 317 meningotheliomatous or fibroblastic meningiomas the proportion of calcification was 31 per cent (the difference of these percentages is highly significant) .

Wender and Hierowski ${ }^{32}$, studying the biochemistry of gliomas, did not find a correlation between $\mathrm{Ca}$ contents and histological signs of calcification. In our material, likewise, no definitive correlation was found between $\mathrm{Ca}$ level and presence of calcifications on the X-ray pictures.

The sole biochemical study comparing meningiomas and normal meninges that we could find in a survey of the literature is the investigation of Cain et al. ${ }^{4}$ on the concentration of lipides, particularly the proportion of hydrocarbons. These authors found a greater percentage of lipides in the meningiomas than in the normal meninges. Moreover, the composition of hydrocarbons in the two tissues was different and the neoplasm contained almost five times as much squalene as the membrane; this hydrocarbon is most likely involved in the cholesterol synthesis.

The findings of Cain et al. 4 and our results in the study of the inorganic elements are probably related to a difference in the metabolic activity of the normal pachymeninx and the meningeal neoplasm.

\section{S U M M A R Y}

The concentrations of $\mathrm{Cu}$, ceruloplasmin, $\mathrm{Mg}$ and $\mathrm{S}$ in the blood serum of eight patients with meningioma were significantly higher than the normal levels. $\mathrm{Ca}, \mathrm{P}, \mathrm{Cu} . \mathrm{Mg}, \mathrm{Na}$ and $\mathrm{K}$ contents in the tumour itself of the same patients plus one were compared with the concentrations in the normal dura mater of human brain. The contents of all elements were significantly increased, except the mean $\mathrm{Ca}$ in six meningotheliomatous or fibroblastic meningiomas when this group was studied apart. The psammomatous tumours had higher concentrations of $\mathrm{Ca}, \mathrm{Cu}$ and $\mathrm{Mg}$ than the other histologic types. No significant correlation was found between the concentrations of the element in the neoplastic tissue and the duration of symptoms or the tumour size, except a negative correlation between $\mathrm{Cu}$ levels and tumour size.

R E S U O

Bioquímica dos meningiomas: conteúdo de cobre, ceruloplasmina, magnésio e enxôfre no sôro sangüineo, e conteúdo de cálcio, fósforo, cobre, magnésio, sódio e potássio no tecido tumoral.

As concentrações de $\mathrm{Cu}$, ceruloplamina, $\mathrm{Mg}$ e $\mathrm{S}$ no sôro de 8 pacientes com meningioma foram significantemente mais elevadas que os níveis normais. Os teores de $\mathrm{Ca}, \mathrm{P}, \mathrm{Cu}, \mathrm{Mg}, \mathrm{Na}$ e $\mathrm{K}$ no próprio tumor dos mesmos 
pacientes e de um outro foram comparados com as concentrações na dura máter normal do cérebro humano. Os valôres de todos os elementos foram significantemente mais altos no tecido tumoral, exceto o conteúdo médio de $\mathrm{Ca}$ em 6 meningiomas meningoteliomatosos ou fibroblásticos, quando êste grupo foi estudado à parte. Os tumores psamomatosos mostraram maiores concentrações de $\mathrm{Ca}, \mathrm{Cu}$ e $\mathrm{Mg}$ que os outros tipos histológicos. Não foi verificada correlação significante entre as concentrações dos elementos no tecido neoplásico e a duração dos sintomas ou o volume do tumor, exceto uma correlação negativa entre os níveis de $\mathrm{Cu}$ e o volume do tumor.

REFEREN CES

1. ALEXANDER, L. \& MYERSON, A. - Minerals in normal and pathologic tissue, studied by micro-incineration and spectroscopy. Arch. Neurol. Psychiat. (Chicago) 39:131, 1938.

2. BAILEY, P. \& BUCY. P. C. - Thë origin and nature of meningeal tumors. Amer. J. Cancer 15:15, 1931.

3. BERNSTEIN, L. \& WEATHERAL, M. - Statistics for Medical and other Biological Students. Livingstone, Edinburgh, 1952.

4. CAIN, C. E.; BELL Jr., O. E.; WHITE Jr., H. B.; SULYA, L. L. \& SMITH, R. R. - Hydrocarbons from human meninges and meningiomas. Biochim. biophys. Acta 144:493, 1967.

5. CANElas. H. M.; De JORGE, F. B.; AISEN, J. \& ANGHINAH, A. Biochemistry of the normal dura mater of the human brain: determination of water, sodium, potassium, calcium, phosphorus, magnesium, copper, iron, sulfur and nitrogen contents. Arq. Neuro-psiquiat. (São Paulo) 27:85, 1969.

6. CANElas, H. M.; De JORGE, F. B.; PEREIRA, W. C. \& SAlluM, J. Biochemistry of cerebral tumors: sodium, potassium, calcium, phosphorus, magnesium, copper and sulphur contents of astrocytomata, medulloblastomata and glioblastomata multiforme. J, Neurochem. 15:1455, 1968.

7. CLARK, E. C. \& COLLIP, J. B. - A study of the Tisdall method for the determination of blood serum calcium, with a suggested modification. J. biol. Chem. 63:461, 1925 .

8. De JoRGE, F. B. \& CANELAS, H. M. - Contribuição ao estudo da ceruloplasmina: valôres normais no sôro sangüíneo. Arq. Neuro-psiquiat. (São Paulo) 22:271, 1964 .

9. De JORGE, F. B.; CANELAS, H. M. \& COSTA-SIlvA, A. - Contribuicão ao estudo do metabolismo do cobre. I: Metodologia da determinação do cobre em materiais biológicos. Rev. paul. Med. 61:350, 1962.

10. De JORGE, F. B.; CANELAS, H. M. \& SPINA-FRANCA, A. - Contribuição ao estudo do metabolismo do cobre. II: Valôres normais no sôro sanguíneo, líquido cefalorraqueano e urina. Rev. paul. Med. 62:125, 1963.

11. De JORGE, F. B.; CANELAS, H. M. \& ZANINI, A. C. - Metabolismo do magnésio. II: Valôres normais no sôro, plasma, sangue total, liquido cefalorraqueano, urina e fezes. Rev. paul. Med. 65:95, 1964. 
12. De JORGE, F. B.; CANELAS, H. M. \& ZANINI, A. C. - Metabolismo do enxôfre. II: Valôres normais no sôro sangüíneo, liquido cefalorraqueano, saliva, urina e fezes. Rev. paul. Med. 65:332, 1964.

13. De JORGE, F. B.; SIlvA, A. G. \& CINTRA, A. B. U. - Determinação quantitativa do magnésio nos materiais biológicos. Rev. paul. Med. 64:224, 1964.

14. De JORGE, F. B.; SIlVA, A. G. \& CINTRA, A. B. U. - Determinação quantitativa do enxôfre nos materiais biológicos. Rev. bras. Med. 21:491, 1964.

15. De JORGE, F. B.; CANATO, C. \& DELASCIO, D. - Biochemical studies on fibroleiomyoma. Matern. e Inf. (São Paulo) 24:649, 1965.

16. De JORGE, F. B.; GOES Jr., J. S.; GuedES, J. L. \& CINTRA, A. B. U. - Biochemical studies on copper, copper oxidase, magnesium, sulfur, calcium and phosphorus in cancer of the breast. Clin. chim. Acta 12:403, 1965.

17. De JORGE, F. B.; PAIVA, L.; MION, D. \& NOVA, R. - Biochemical studies on copper, copper oxidase, magnesium, sulfur, calcium and phosphorus in cancer of the larynx. Acta oto-laryng. (Stockholm) 61:454, 1966.

18. FISKE, C. H. \& SUBBAROW, Y. - The colorimetric determination of phosphorus. J. biol. Chem. 66:375, 1925.

19. GEBHARDT, K. H. \& BOHNDORF, W. - Der Serummagnesiumspiegel bei Krebskranken vor und nach Telekobaltbestrahlung. Med. Klin. 58:369, 1963.

20. GRASHCHENKOV, N. I. \& HEKHT, B. M. - Copper content of brain tissues in health and in certain nervous diseases. Exp. Neurol, 2:573, 1960.

21. GULKO, I. S. - The contents of zinc, copper, manganese, cadmium, cobalt and nickel in the blood, organs and tumours of cancer patients. Vopr. Onkol. $7 / 9: 46,1961$.

22. HEILMEYER, L.; KEIDERLING, W. \& STUWE, G. - Kupfer und Eisen als körpereigene Wirkstoffe und ihre Bedeutung beim Krankheitsgeschehen. Gustav Fisher, Jena, 1941.

23. HOUCHIN, O. B. - A rapid colorimetric method for the quantitative determination of copper oxidase activity (ceruloplasmin). Clin. Chem. 4:519, 1958 .

24. HUH, K. - Study of the incidence of calcification in a histological survey of surgery biopsies of meningiomas. J. Neurosurg. 21:751, 1964.

25. KEIDERLING, W. \& SCHARPF, H. - Uber die klinische Bedeutung der Serumkupfer und Serumeisenbestimmung bei neoplastischen Krankheitszuständen. Münch. med. Wschr. 95:437, 1953.

26. KOCH Jr., H. J.; SMITH, E. R. \& MCNEELY, J. - Analysis of trace elements in human tissues. II: The lymphomatous diseases. Cancer 10:151, 1957.

27. LONG, C.; KING, E. J. \& SPERRY, W. M. - Biochemist's Handbook. Spon, London, 1961, p. 780.

28. PAGLIARDI, E. \& GIANGRANDI, E. - Clinical significance of the blood copper in Hodgkin's disease. Acta haemat. (Basel) 24:201, 1960. 
29. PIRRIE, R. - Serum copper and its relationship to serum. iron in patients with neoplastic disease. J. clin. Path. 5:190, 1952.

30. PISKAZECK, K.; BILEK, K. \& ROTHE, K. - Zum Verhalten des Serumkupfers bei weiblichen Genitalcarcinomen in Abhängigkeit vor der Lokalisation und der Therapieform. Arch. Gynäk. 196:447, 1962.

31. SCHRUMPF-PIERRON, P. - Die Seltenheit des Krebses in Ägypten und ihre 'wahrscheinlichen Gründe: ein Beitrag zur Atiologie des Carcinoms. $Z$. Krebsforsch . 36:145, 1932.

32. WENDER, M. \& HIEROWSKI, M. - Der Gehalt an Mineralsbeswtandtellen in Hirngeschwülsten. Zbl. allg. Path. path. Anat. 101:120, 1960.

33. WOHLER, F. \& ARDEN, S. - Uber den Kupergehalt menschlicher Orgam bei verschiedenen Krankheitszuständen. Klin. Wschr. 41:509, 1963.

Departamento de Neurologia - Faculdade de Medicina da Universidade de São Paulo - Caixa Postal $\$ 461$ - São Paulo, SP - Rrasil. 